\title{
EFFECTS OF SHORT-TERM STRENGTH TRAINING ON BODY COMPOSITION, MUSCLE STRENGTH AND FUNCTIONAL CAPACITY OF ELDERLY: A SYSTEMATIC REVIEW AND META-ANALYSIS
}

\author{
EFEITOS DO TREINAMENTO DE FORÇA DE CURTA DURAÇÃO SOBRE A \\ COMPOSIÇÃO CORPORAL, A FORÇA MUSCULAR E A CAPACIDADE \\ FUNCIONAL DE IDOSOS: REVISÃO SISTEMÁTICA E META-ANÁLISE
}

\author{
Osvaldo C. MOREIRA ${ }^{1}$; Claudia E. P. OLIVEIRA ${ }^{2}$; Sergio MAROTO-IZQUIERDO³ \\ María J. CUEVAS ${ }^{4}$; José A. DE PAZ ${ }^{5}$ \\ 1. Physical education teacher, Doctor in Physical Activity Sciences and Sports, Institute of Biological Sciences and Health, Federal \\ University of Viçosa, Campus Florestal, Florestal, MG, Brazil; 2. Physical education teacher, Doctor in Physical Activity Sciences and \\ Sports, Department of Physical Education, Federal University of Viçosa, Campus Viçosa, Viçosa, MG, Brazil; 3. Physical education \\ teacher, Doctor in Physical Activity Sciences and Sports, Institute of Biomedicine, University of Leon, Leon, Spain; 4. Biologist, Doctor \\ in Biology, Institute of Biomedicine, University of Leon, Leon, Spain; Physician, Doctor in Medicine, Institute of Biomedicine, \\ University of Leon, Leon, Spain.
}

\begin{abstract}
To examine the effects of short-term strength training (STST) on different manifestations of muscle strength in the lower limbs, functional capacity and body composition of people 65 years old or older. We searched the electronic databases (PubMed, Web of Science and Cochrane) to identify all publications using STST (up to 12 weeks) in people aged 65 or older, published in the last five years, prior to May 2018. Results were analyzed as continuous data using random effects to calculate the standardized mean difference (SMD) and the 95\% confidence interval $(95 \% \mathrm{CI}) .28$ studies with 921 subjects met the inclusion criteria and were analyzed. These works were grouped into three categories for analysis: Muscular Strength, Functional Capacity and Body Composition. In Muscular Strength category, the overall pooled effect estimate was 0.95 (95\% CI: 0.63; 1.26), with a significant STST effect $(Z=5.93 ; p<0.001)$, over the different strength manifestations analyzed. In Functional Capacity category, the STST decreased the Time Up-and-Go test run time (SMD: $-1.01 ; 95 \% \mathrm{CI}:-1.56$; -0.47 ) and increased the repetitions' number performed in 30 -s chairstand test (SMD: 1.07, 95\% CI: 0.79, 1.34). In Body Composition category, the overall pooled effect estimate was $0.13(95 \% \mathrm{CI}$ : $-0.16 ; 0.42)$, without finding a significant effect of STST $(Z=0.87 ; p=0.38)$. STST has a moderate to large effect in improving the different manifestations of muscle strength and functional capacity. However, this type of intervention has no effect on body composition.
\end{abstract}

KEYWORDS: Resistance training. Muscle power. Muscle strength. Body Composition, Aged.

\section{INTRODUCTION}

From a biomedical perspective, the term aging refers to changes in molecules, cells, populations or species over time. This process is characterized by the accumulation of errors at the molecular and cellular level that are manifested by a functional decline at tissues and organs level (ZANG et al., 2016; ZANG, 2015). The aging process promotes changes in body composition, causing the rate of loss of muscle mass (MM) in individuals older than 50 years to be 1 to $2 \%$ per year, while the rate of muscle strength loss reaches values yearly from 1.5 to $3 \%$ and the rate of annual bone mass loss is 1 to $2 \%$ (CURTIS et al., 2015). All these changes lead to an increase in the risk of fractures as age increases. It is estimated that after the fifth decade of life, one in two women and one in five men will suffer a fracture due to bone fragility (LORENTZON; CUMMINGS, 2015).

The American College of Sports Medicine (ACSM, 2011; ACSM, 2009) states that regular physical activity practice in older people result in positive adaptations in the body that contribute to a healthy aging. It demonstrates a reduced risk of developing the fragility syndrome and the risk of falls, as well as improving physical capacity, balance, mobility, muscular strength/power, body composition and functional capacity. In particular, strength training seems to promote more consistent results in functional capacity (BRADY; STRAIGHT; EVANS, 2014), in MM and muscle strength, during the aging process (BROOK et al., 2016).

In this line, different research groups are studying the effects of strength training in older people, using different methods and training 
strategy (MATOS et al., 2017; RAMIREZCAMPILLO et al., 2017; MAZINI-FILHO et al., 2018; FRANK et al., 2016; FRAGALA et al., 2014; PINTO et al., 2014). Among the different strategies is short-term strength training (STST). This training type refers to programs lasting up to 12 weeks (FARINATTI et al., 2016; KIMURA et al., 2010; LOWNDES et al., 2009), although some authors consider up to 16 weeks (MORAN et al., 2017).

Studies using STST in older people wear different strategies, such as functional training (MATOS et al., 2017), high-speed strength training (RAMIREZ-CAMPILLO et al., 2017), elastic bands strength training (KIM et al., 2015) or traditional strength training (ZHAO et al., 2017), with a large range of volumes and intensities. This contributes to explain the heterogeneous character of results obtained between studies.

Because low muscle strength levels are associated with lower functional capacity in older people, muscle strength is a strong predictor of functional limitation, disability and even mortality (BUCH et al., 2016; BORDE; HORTOBÁGYI; GRANACHER, 2015; SCHAAP; KOSTER; VISSER, 2013). The use of short-term interventions that increase short-term strength levels in these older people may contribute to improved functional autonomy and physical conditioning to support higher loads in long-term training programs.

Based on this premise, the aim of this systematic review and meta-analysis is to systematically review the literature on clinical trials and randomized controlled trials that examined the effects of STST in people 65 years old or older, without associated diseases, and how this intervention affects the different manifestations of muscle strength in the lower limbs, functional capacity and body composition. It was hypothesized that subjects who performed STST would significantly increase the different muscle strength manifestations in the lower limbs, as well as the functional capacity when comparing them with people with similar characteristics that did not perform training. In addition, it was also hypothesized that STST is capable of producing increases in $\mathrm{MM}$ and reductions in fat mass (FM).

\section{MATERIAL AND METHODS}

\section{Data sources}

This systematic review was designed following the guidelines of the Preferred Reporting Items for Systematic Reviews and Meta-Analyzes (PRISMA). A systematic literature search was conducted in the PubMed, Web of Science electronic databases and the Cochrane Central Register of Controlled Trials from January 2012 to May 2018. The search was performed using the $\mathrm{MeSH}$ terms "strength training" and "resistance training" in combination with "elderly", "older" and "aged" (to exact search terms in different databases, see Table 1), in the title, abstract, and keywords. The studies quality evaluation, the decision on their inclusion in this review and the data extraction were made by two independent researchers. Initial discrepancies between researchers were resolved by consensus. In cases where discrepancies could not be resolved, the final decision was made by another independent researcher.

Table 1. Detailed listing of articles found and search terms applied in the selected databases.

\begin{tabular}{|c|c|c|}
\hline Database & Articles found & MeSH terms \\
\hline PubMed & 236 & $\begin{array}{l}\text { ("resistance training" OR "strength training") AND } \\
\text { (older OR aged OR elderly) }\end{array}$ \\
\hline Cochrane & 125 & $\begin{array}{l}\text { ("resistance training" OR "strength training") AND } \\
\text { (older OR aged OR elderly) }\end{array}$ \\
\hline Web of Science & 302 & $\begin{array}{l}\text { ("resistance training" OR "strength training") AND } \\
\text { (older OR aged OR elderly) }\end{array}$ \\
\hline
\end{tabular}

\section{Inclusion and Exclusion Criteria}

We selected randomized controlled trials and clinical trials published in English in the last five years examining the effect STST on different muscle strength manifestations, functional capacity and body composition in people 65 years old or older. It was considered STST an intervention in which the participants exercised the lower limbs against external strength, with bilateral evaluation. Participants should be randomized, a control group of people 65 years old or older should be included, and the intervention should extend a maximum of 12 weeks. The exclusion criteria were: case studies, observational studies, studies with young comparison groups, studies employing additional therapies or intervention other than strength training, and studies where older people had some associated disease. To perform the meta-analysis, in addition to the criteria already indicated, another criterion of exclusion was not to provide data about 
the sample size, mean and standard deviation of the interest variables.

\section{Data extraction}

With the use of an extraction form, some methodological details of each study were recorded, as described in Table 2, in which the publication data (authors), number of participants (control group and experimental group), type, duration, frequency, intensity and volume of the intervention, as well as a summary of main results related to interest variables (different muscle strength manifestations, functional capacity and body composition), are presented.

Table 2. Characteristics of randomized controlled trials and clinical trials examining the STST effects on different lower limb strength manifestations, functional capacity and body composition of elderly people.

\begin{tabular}{|c|c|c|c|c|c|c|c|c|c|}
\hline Study & Type & $\mathrm{CG}$ & EG & Dur. & Freq. & Inten. & Series & Rep. & Main outcomes \\
\hline $\begin{array}{l}\text { Correa et } \\
\text { al. }(2012) \\
\text { Delshad et }\end{array}$ & TST & 17 & 42 & 6 & 2 & 12 a $15 \mathrm{RM}$ & 2 a 3 & 12 a 15 & $\uparrow:$ MDVC, MM, FC; \\
\hline $\begin{array}{l}\text { al. (2013) } \\
\text { Emerson }\end{array}$ & EBST & 10 & 10 & 12 & 3 & 80 a $100 \%$ RM & 3 & 10 & $\uparrow: \mathrm{MM} ; \downarrow: \mathrm{FM}$ \\
\hline $\begin{array}{l}\text { et al. } \\
\text { (2015) } \\
\text { Fragala et }\end{array}$ & TST & 12 & 11 & 6 & 2 & 70 a $85 \%$ RM & 3 & 8 a 15 & $\uparrow:$ MDVC, FC; $\leftrightarrow:$ MM, FM \\
\hline $\begin{array}{l}\text { al. }(2014) \\
\text { Frank et }\end{array}$ & TST & 11 & 12 & 6 & 2 & 5 a 6 OMNI & 3 & 8 a 15 & $\uparrow: \mathrm{FC} ; \leftrightarrow: \mathrm{MM}$ \\
\hline $\begin{array}{l}\text { Frank et } \\
\text { al. }(2016)\end{array}$ & TST & 9 & 12 & 8 & 3 & 75 a $80 \%$ RM & 3 & 12 & $\uparrow:$ MDVC, MM \\
\hline $\begin{array}{l}\text { Gennuso } \\
\text { et al. } \\
(2013)\end{array}$ & TST & 13 & 12 & 8 & 2 & 5-6 OMNI & 1 & 8 & $\uparrow:$ MDVC \\
\hline $\begin{array}{l}\text { Gerage et } \\
\text { al. (2013) }\end{array}$ & TST & 14 & 15 & 12 & 3 & $15 \mathrm{RM}$ & 2 & 10 a 15 & $\uparrow:$ MDVC; $\leftrightarrow:$ MM, FM \\
\hline $\begin{array}{l}\text { Granacher } \\
\text { et al. } \\
(2013)\end{array}$ & FT & 16 & 16 & 9 & 2 & NR & 3 a 4 & 15 a 20 & $\uparrow: \mathrm{FC}$ \\
\hline $\begin{array}{l}\text { Gurjão et } \\
\text { al. (2012) } \\
\text { Kim et al. }\end{array}$ & TST & 7 & 10 & 8 & 3 & 10 a $12 \mathrm{RM}$ & 3 & 10 a 12 & $\uparrow:$ MIVC \\
\hline $\begin{array}{l}(2015) \\
\text { Kobayashi } \\
\text { et al. }\end{array}$ & EBST & 8 & 22 & 12 & 2 & 12 a 13 RPE & 2 a 3 & 12 a 15 & $\uparrow:$ MDVC; $\leftrightarrow:$ MM, FM \\
\hline $\begin{array}{l}(2016) \\
\text { Lee; Park }\end{array}$ & EST & 24 & 32 & 4 & 2 & $10 \mathrm{RM}$ & 3 & 10 & $\uparrow:$ MIVC, MM \\
\hline $\begin{array}{l}\text { (2013) } \\
\text { Lohne- } \\
\text { Seiler; } \\
\text { Torstveit; } \\
\text { Anderssen }\end{array}$ & TST & 20 & 30 & 12 & 2 & 45 a $75 \%$ RM & 3 & 10 a 12 & $\uparrow: \mathrm{FC}$ \\
\hline $\begin{array}{l}(2013) \\
\text { Lubans et }\end{array}$ & HSST & 10 & 23 & 11 & 2 & 60 a $80 \%$ RM & 3 & 10 a 12 & $\uparrow:$ MDVC; $\leftrightarrow:$ POW \\
\hline $\begin{array}{l}\text { al. (2013) } \\
\text { Martins et }\end{array}$ & EBST & 22 & 22 & 8 & 2 & 12 a 16 RPE & 2 & 10 a 15 & $\uparrow:$ FC \\
\hline $\begin{array}{l}\text { al. (2015) } \\
\text { Mejías- }\end{array}$ & EBST & 20 & 20 & 8 & 2 & 8 a 10 OMNI & 2 a 3 & 15 & $\leftrightarrow: \mathrm{MM}, \mathrm{RM}$ \\
\hline $\begin{array}{l}\text { Peña et al. } \\
\text { (2017) } \\
\text { Pinto et al. }\end{array}$ & TST & 10 & 16 & 8 & 2 & 60 a $80 \%$ RM & 3 & 10 a 12 & $\uparrow:$ MDVC, MIVC \\
\hline$(2014)$ & TST & 17 & 19 & 6 & 2 & 12 a $20 \mathrm{RM}$ & 2 a 3 & 12 a 20 & $\uparrow:$ MDVC, FC, MM \\
\hline
\end{tabular}


Ramirez-

Campillo

et al.

(2014)

$\begin{array}{lllll}\text { HSST } & 15 & 30 & 12 & 3\end{array}$

45 a $70 \%$ RM $3 \quad 8$

$\uparrow:$ MDVC, POW, FC

Ramirez-

Campillo

et al.

(2017)

Rodriguez-

Miguelez

et al.

(2014)

TST $10 \quad 16 \quad 8 \quad 2$

60 a $80 \%$ RM 3

10 a $12 \uparrow:$ MIVC

Sayers;

Gibson

(2014)

Scalon et

al. (2014)

$\begin{array}{lllll}\text { HSST } & 18 & 24 & 12 & 2\end{array}$

$40 \% \mathrm{RM}$

3

12 a $14 \uparrow:$ MDVC, POW

Silva

Correa et

al. (2014)

$\begin{array}{lllll}\text { TST } & 12 & 13 & 6 & 2\end{array}$

70 a $85 \%$ RM

2 a 4

8 a $12 \uparrow:$ MDVC; $\leftrightarrow:$ MM, FM

Smolarek

et al.

(2014)

Valls et al.

(2014)

Walker;

$\begin{array}{lllllll}\text { TST } & 33 & 17 & 6 & 2 & 8 \text { a } 12 & \text { RM }\end{array}$

3 a $4 \quad 8$ a $12 \quad \uparrow: F C ; \leftrightarrow:$ MIVC, MM, FM

Häkkinen

(2014)

Zech et al.

(2012)

$\begin{array}{lllll}\text { TST } & 11 & 26 & 10 & 2\end{array}$

60 a $85 \%$ RM

3

10

$\uparrow: F C$

Zhao et al.

$\begin{array}{lllll}\text { TST } & 22 & 20 & 12 & 2\end{array}$

12 a 16 RPE $2 \quad 15$

8 a $14 \uparrow:$ MDVC, MIVC; $\leftrightarrow:$ MM

(2017)

$\begin{array}{lllll}\text { TST } & 7 & 10 & 12 & 2\end{array}$

NR

NR NR $\quad \downarrow: F M$

CG: control group simple size; EG: experimental group simple size; Dur.: training duration in weeks; Freq.: weekly training frequency; Inten.: training intensity; Rep.: number of repetitions; TST: traditional strength training; EBST: elastic bands strength training; FT: functional training; EST: explosive strength training; HSST: high-speed strength training; RPE: rating of perceived exESTion; NR: not reported; MDVC: maximum dynamic voluntary contraction; MIVC: maximum isometric voluntary contraction; POW: muscle power; FC: functional capacity; MM: muscle mass; FM: fat mass.

\section{Quality assessment}

All articles that met the predefined inclusion criteria were evaluated using the Physiotherapy Evidence Database scale (PEDro). The PEDro scale is composed of 11 items that evaluate the methodological quality of intervention studies and the following methodological aspects: 1.Eligibility criteria reported; 2. Random assignment; 3. Concealed allocation; 4. Groups similar at baseline regarding most important prognostic indicator; 5 . Blinding of participants; 6 . Blinding of therapists; 7.
Blinding of assessors who measured key outcome; 8. Measures of at least one key outcome were obtained from more than $85 \%$ of initial participants; 9. All participants received treatment or control condition as allocated; 10. Results of between-group statistical comparisons are reported; 11. Study provides point measures and measures of variability for at least one key outcome. When rating each study, a minimum value of $6 / 11$ was considered in the PEDro scale for inclusion in the systematic review, as described in Table 3.

Table 3. Methodological quality of articles evaluated by PEDro scale.

\begin{tabular}{lcccccccccccc}
\hline & Criterion & & & & & & & \\
Study & 1 & 2 & 3 & 4 & 5 & 6 & 7 & 8 & 9 & 10 & 11 & Total \\
\hline Correa et al. (2012) & + & + & - & + & - & - & - & + & + & + & + & $7 / 11$ \\
Delshad et al. (2013) & + & + & - & + & - & - & - & + & + & + & + & $7 / 11$
\end{tabular}


Emerson et al. (2015)

Fragala et al. (2014)

Frank et al. (2016)

Gennuso et al. (2013)

Gerage et al. (2013)

Granacher et al. (2013)

Gurjão et al. (2012)

Kim et al. (2015)

Kobayashi et al. (2016)

Lee; Park (2013)

Lohne-Seiler; Torstveit; Anderssen (2013)

Lubans et al. (2013)

Martins et al. (2015)

Mejías-Peña et al. (2017)

Pinto et al. (2014)

Ramirez-Campillo et al. (2014)

Ramirez-Campillo et al. (2017)

Rodriguez-Miguelez et al. (2014)

Sayers; Gibson (2014)

Scalon et al. (2014)

Silva Correa et al. (2014)

Smolarek et al. (2014)

Valls et al. (2014)

Walker; Häkkinen (2014)

Zech et al. (2012)

Zhao et al. (2017)

\begin{tabular}{llllllllllll}
+ & + & - & + & - & - & - & + & + & + & + & $7 / 11$ \\
+ & + & - & + & - & - & - & + & + & + & + & $7 / 11$ \\
+ & + & - & + & - & - & - & + & + & + & + & $7 / 11$ \\
+ & + & - & + & - & - & - & + & + & + & + & $7 / 11$ \\
+ & + & - & + & - & - & - & + & + & + & + & $7 / 11$ \\
+ & + & - & + & - & - & - & + & + & + & + & $7 / 11$ \\
+ & + & - & + & - & - & - & + & + & + & + & $7 / 11$ \\
+ & + & - & + & - & - & - & - & + & + & + & $6 / 11$ \\
+ & + & - & + & - & - & - & + & + & + & + & $7 / 11$ \\
+ & + & - & + & - & - & - & - & + & + & + & $6 / 11$ \\
+ & + & - & + & - & - & - & - & + & + & + & $6 / 11$ \\
+ & + & - & + & - & - & - & + & + & + & + & $7 / 11$ \\
+ & + & - & + & - & - & - & + & + & + & + & $7 / 11$ \\
+ & + & - & + & - & - & - & + & + & + & + & $7 / 11$ \\
+ & + & - & + & - & - & - & + & + & + & + & $7 / 11$ \\
+ & + & - & + & - & - & - & + & + & + & + & $7 / 11$ \\
+ & + & - & + & - & - & - & + & + & + & + & $7 / 11$ \\
+ & + & - & + & - & - & - & + & + & + & + & $7 / 11$ \\
+ & + & - & + & - & - & - & + & + & + & + & $7 / 11$ \\
+ & + & - & + & - & - & - & + & + & + & + & $7 / 11$ \\
+ & - & - & + & - & - & - & + & + & + & + & $6 / 11$ \\
+ & + & - & + & - & - & - & + & + & + & + & $7 / 11$ \\
+ & + & - & + & - & - & - & + & + & + & + & $7 / 11$ \\
+ & + & - & + & - & - & - & + & + & + & + & $7 / 11$ \\
+ & + & - & + & - & - & - & + & + & + & + & $7 / 11$ \\
+ & + & - & + & - & - & - & + & + & + & + & $7 / 11$ \\
\hline
\end{tabular}

when selected articles did not provide sufficient data for the analysis, authors were contacted to obtain the relevant information.

\section{RESULTS}

Figure 1 shows a flow chart with the different phases of the search and selection of studies included in the review. The initial search for electronic databases identified 663 titles, of which 431 were rejected for additional intervention associated with strength training, because they were performed in people with an associated disease or because they were not randomized controlled trials and clinical trials. In addition, 88 studies were excluded because of duplicity problems. Thus, a total of 144 abstracts were examined, of which 108 were excluded for: not having a control group, not evaluating any variable of interest, presenting additional therapies or intervention other than strength training, being performed in people with associated disease, being a review, or showing an 
intervention longer than 12 weeks. 36 completed texts were reviewed, being excluded eight studies that did not meet the inclusion criteria. The main reasons for exclusion were: lack of control group $(n=2)$, intervention longer than 12 weeks $(n=1)$, people under 65 years old $(\mathrm{n}=1)$, and not indicating mean, standard deviation and number of participants assigned in each group $(n=4)$. A total of 28 studies were finally included in this systematic review and meta-analysis.
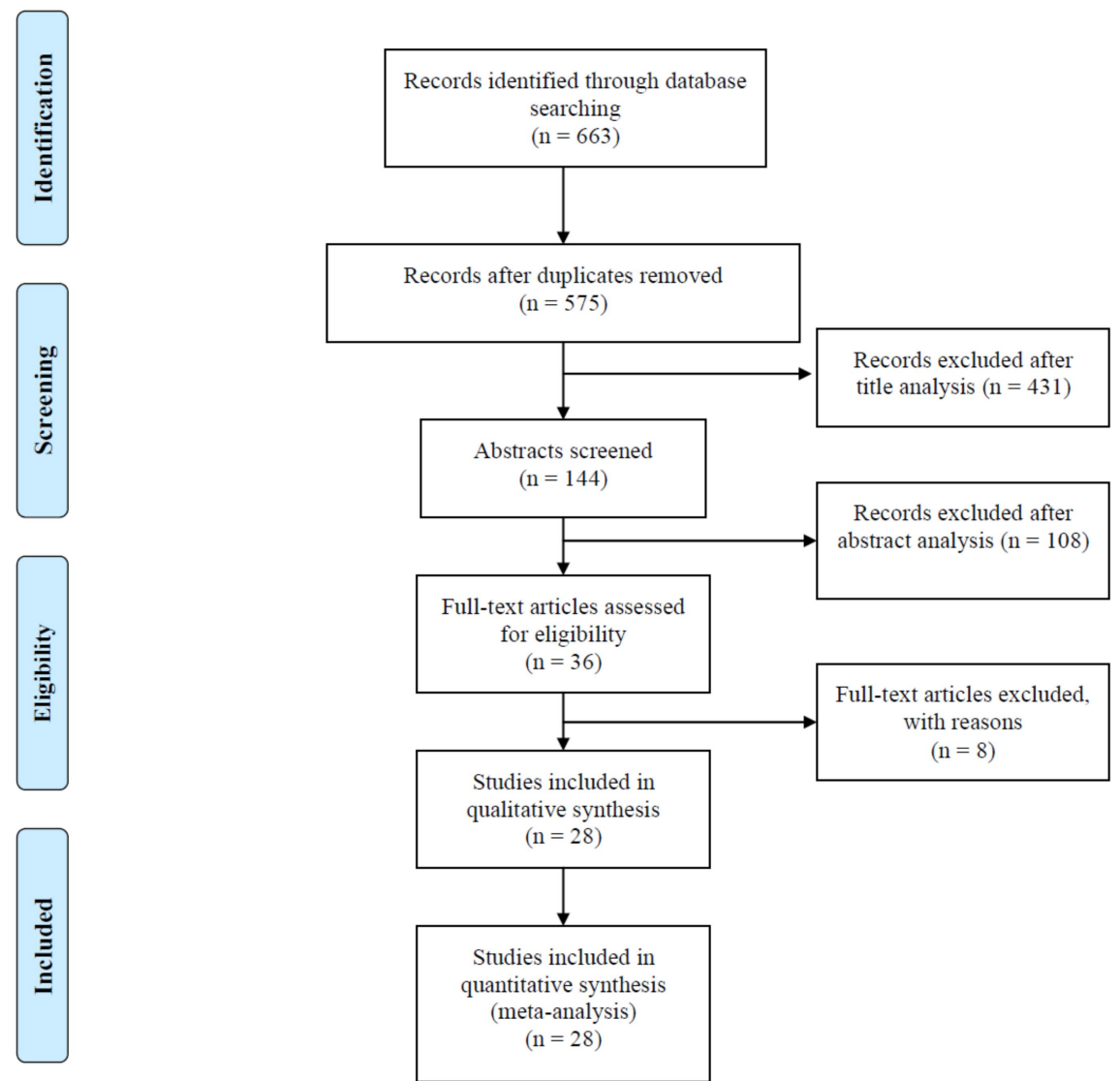

Figure 1. Flow diagram illustrating the different phases of the search and selection of studies included in the review (PRISMA).

The mean methodological quality of the studies on PEDro scale was $6.86 \pm 0.35$, with scores of 6 to 7 . All studies were classified as high quality (MAROTO-IZQUIERDO et al., 2017). The most common defect was lack of blinding of participants, therapists or appraisers. However, blinding of participants in these studies should be considered as a difficult requirement to meet. The reliability among appraisers was significantly high ( $\mathrm{ICC}=$ $0.98)$.

The main features of the studies included in this review with respect to participants, interventions and outcomes are illustrated in Table 2. The total participants' number in the included studies was 921 . Of these, 536 participants $(58.2 \%)$ performed STST and $385(41.8 \%)$ served as controls, without performing any type of systematized training. The main types of strength training used were traditional strength training $(60.71 \%)$, followed by high-speed strength training $(14.29 \%)$ and elastic bands strength training
$(14.29 \%)$. The interventions' duration varied between 4 and 12 weeks, where $42.86 \%$ of the studies had duration of 12 weeks, $25 \%$ of 8 weeks and $17.86 \%$ of 6 weeks. The training frequency was $2(75 \%)$ and $3(25 \%)$ times per week. The intensity in most of the studies was controlled by $1 \mathrm{RM}$ percentage $(50 \%)$, varying between 45 and $100 \%$ of $1 \mathrm{RM}$. The total number of series performed ranged from 1 to 4 series, with most of the studies performing 3 series (50\%). The repetitions' number performed in each series varied between 8 and 20 repetitions, although most of the studies used between 10 and 12 repetitions $(21.43 \%)$.

The main results of analyzed studies were increases of MDVC (CORREA et al., 2012; GERAGE et al., 2013; VALLS et al., 2014; SAYERS; GIBSON, 2014; RAMIREZ-CAMPILLO et al., 2017; RAMIREZ-CAMPILLO et al., 2014; MEJÍAS-PEÑA et al., 2017; SCALON et al., 2014; KIM et al., 2015; GENNUSO et al., 2013; EMERSON et al., 2015; PINTO et al., 2014; 
WALKER; HÄKKINEN, 2014; FRANK et al., 2016; LOHNE-SEILER; TORSTVEIT; ANDERSSEN, 2013), MIVC (GURJÃO et al., 2012; KOBAYASHI et al., 2016; MEJÍAS-PEÑA et al., 2017; RODRIGUEZ-MIGUELEZ et al., 2014; WALKER; HÄKKINEN, 2014), de la potencia muscular (VALLS et al., 2014; SAYERS; GIBSON, 2014; RAMIREZ-CAMPILLO et al., 2017; RAMIREZ-CAMPILLO et al., 2014; ZECH et al., 2012), muscle power (RAMÍREZ-CAMPILLO et al., 2017; VALLS et al., 2014; SAYERS; GIBSON, 2014; RAMÍREZ-CAMPILLO et al., 2014; ZECH et al., 2012) and functional capacity (CORREA et al., 2012; LEE; PARK, 2013; GRANACHER et al., 2013; VALLS et al., 2014; RAMIREZ-CAMPILLO et al., 2017; RAMIREZ-CAMPILLO et al., 2014; FRAGALA et al., 2014; LUBANS et al., 2013; EMERSON et al., 2015; PINTO et al., 2014; SILVA
CORREA et al., 2013; SMOLAREK et al., 2014). In addition, some studies reported increases in MM (CORREA et al., 2012; DELSHAD et al., 2013; KOBAYASHI et al., 2016; PINTO et al., 2014; FRANK et al., 2016) and reduction in FM (ZHAO et al., 2017).

For Muscular Strength category, the overall pooled effect estimate was 0.95 (95\%CI: 0.63 ; 1.26), with a significant STST effect $(Z=5.93$; $\mathrm{p}<0.001$ ), as shown in Figure 2. Likewise, in its MDVC, MIVC and muscle power items, a positive and significant STST effect on these variables was also found. The Meta-analyzes of items showed significant differences in training-induced adaptations for MDVC (SMD: 1.05, 95\%CI: 0.61; 1.50), MIVC (SMD: 0.87, 95\%CI: $0.16 ; 1.58$ ) and muscle power (SMD: $0.79,95 \% \mathrm{CI}: 0.16 ; 1.41$ ).

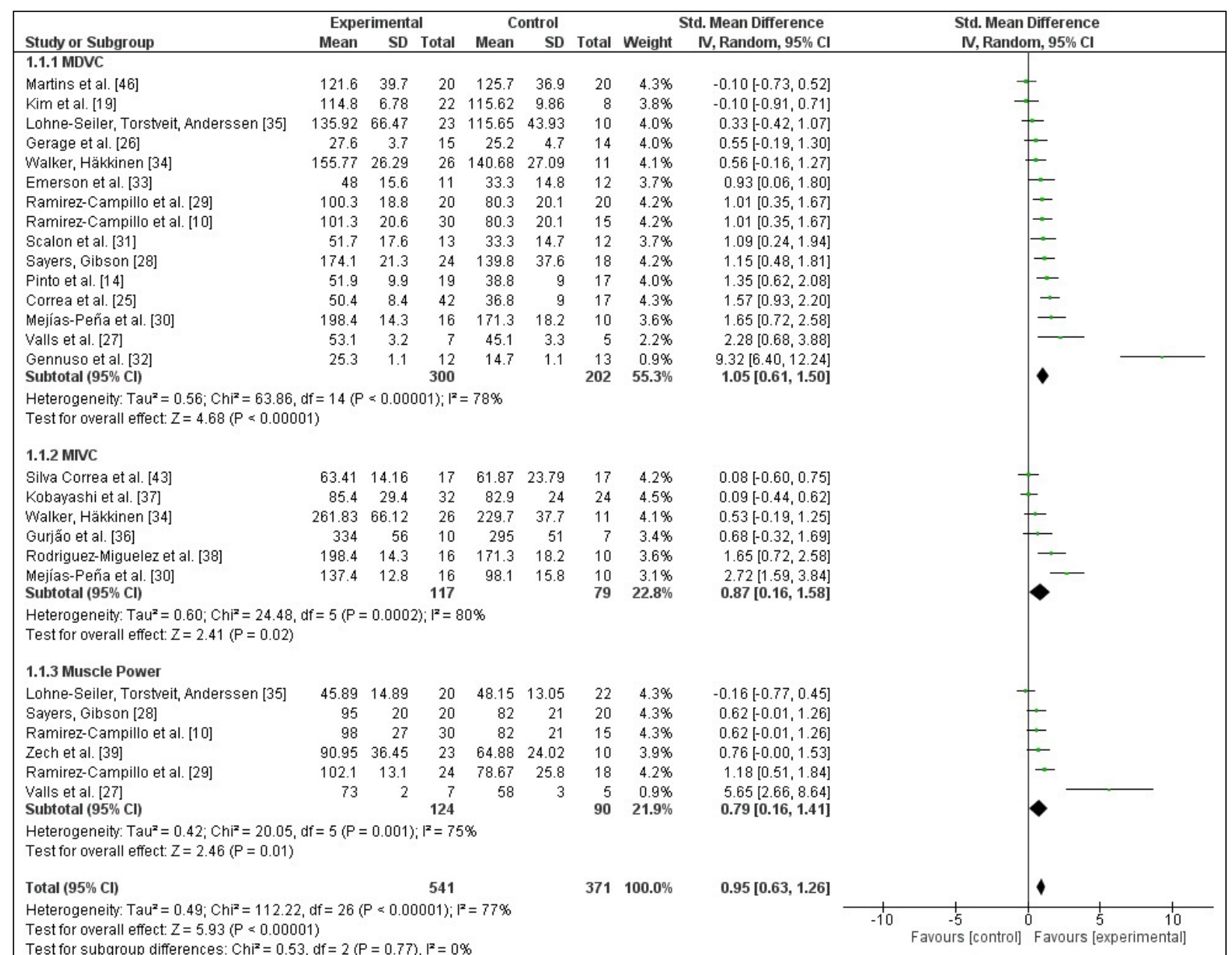

Figure 2. Forest plot with meta-analysis of standardized mean difference showing the effect of short-term strength training on different muscle strength manifestations in elderly.

For Functional Capacity category, the overall pooled effect estimate was $1.05(95 \% \mathrm{CI}$ : $0.80 ; 1.31)$, indicating that there was no significant STST effect $(Z=8.10 ; p<0.001)$, as shown in Figure
3. In the TUG, the meta-analysis indicated that STST has a positive effect on the reduction of the execution time of this test, with a significant overall effect (SMD: 1.01, 95\%CI: 0.47; 1.56). Likewise, 
for the CST, a positive and significant training effect was also observed on the total number of repetitions performed (SMD: 1.07, 95\%CI: 0.79; 1.34).

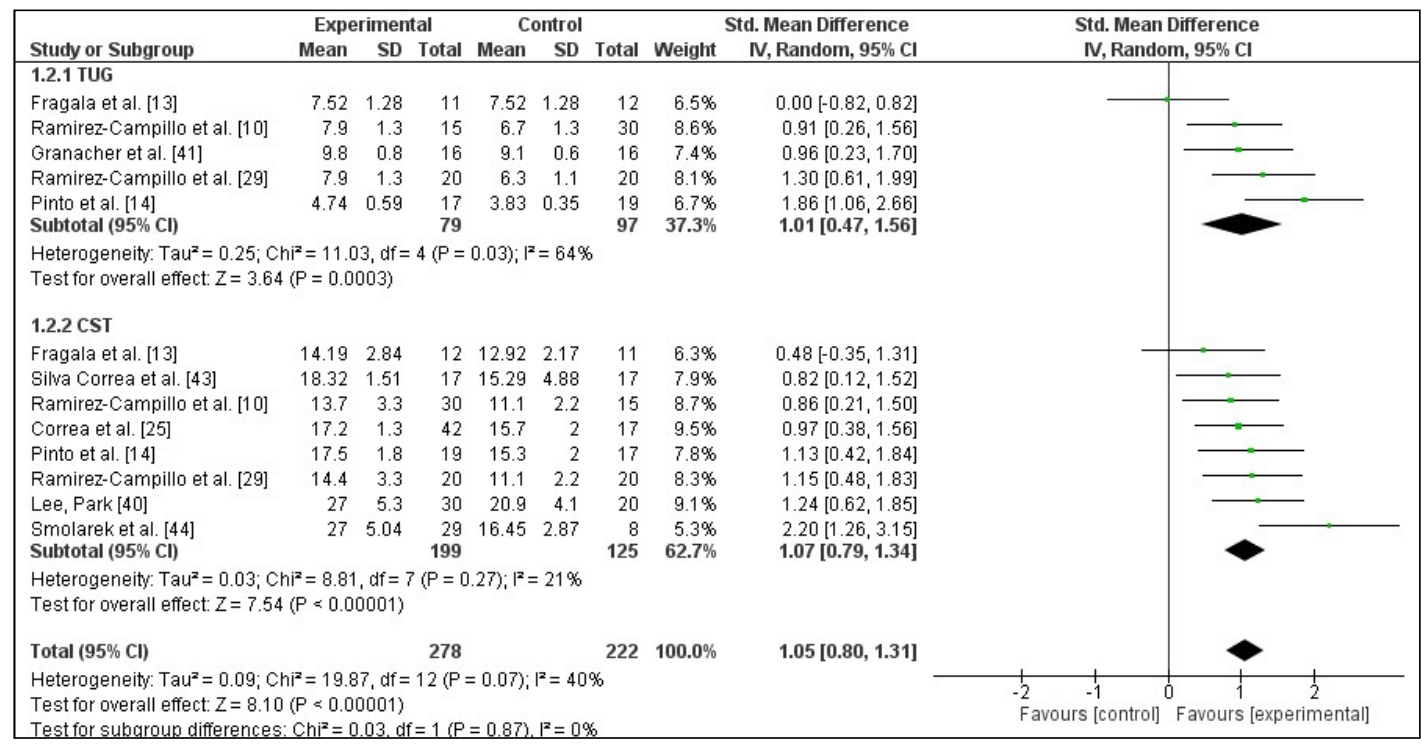

Figure 3. Forest plot with meta-analysis of standardized mean difference showing the effect of short-term strength training on functional capacity tests in elderly.

Finally, for Body Composition category, the overall pooled effect estimate was 0.13 (95\%CI: $0.16 ; 0.42)$, indicating that there was no significant STST effect $(Z=0.87 ; p=0.38)$, as shown in Figure
4. Likewise, in the items MM (SMD: $0.26,95 \% \mathrm{CI}$ : $0.08 ; 0.26$ ) and FM (SMD: -0.18 ; 95\%CI: -0.75 ; 0.39 ) no significant training effect was found either.

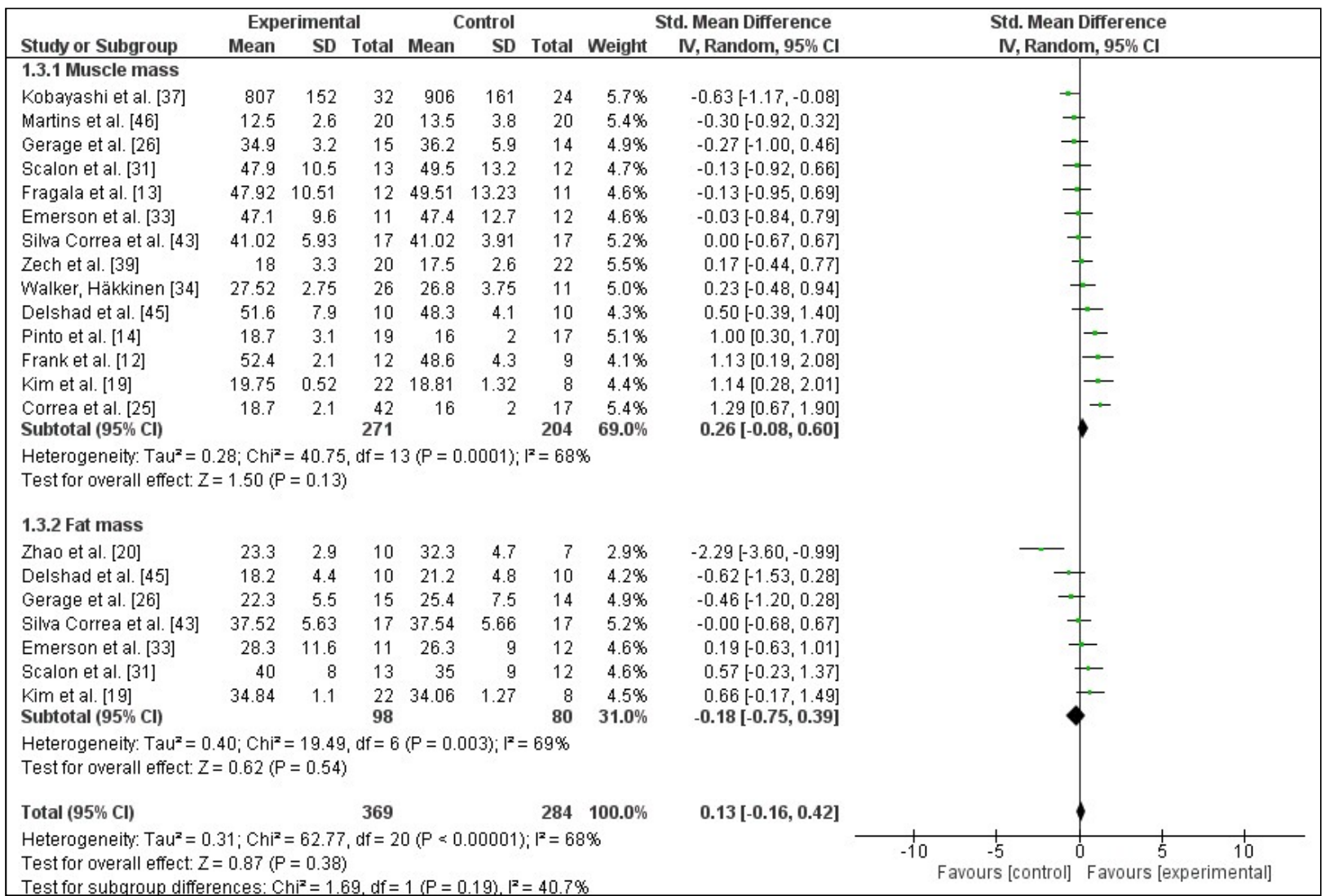


Figure 4. Forest plot with meta-analysis of standardized mean difference showing the effect of short-term strength training on body composition in elderly.

\section{DISCUSSION}

The present study is a systematic review and meta-analysis that analyzes the effects of STST on the different muscle strength manifestations in lower limbs, functional capacity and body composition in people 65 years old or older. The review includes 28 studies that met the inclusion criteria. Data analysis provided by these studies showed strong effects of STST on MDVC, MIVC, muscle power and functional capacity. The heterogeneity reported among studies was mainly caused by the different evaluation methods used for the analyzed variables in each investigation.

During the aging process a clear relationship exists between body composition and functional capacity (KALISH, 2016), with a deterioration of both aspects over the years. It is also possible to observe a deterioration of muscular power and strength levels, especially in lower limbs (BRADY; STRAIGHT; EVANS, 2014). In addition, body composition and muscle function have important implications for falls and fractures in older people. The loss of mass and muscle strength being the main risk factors associated with increased falls and fractures in the hip region (SCOTT et al., 2017). However, strength training can curb that deterioration caused by aging, as well as promote gains in strength or muscle power and increases in $\mathrm{MM}$, associated with improvements in functional capacity (BRADY; STRAIGHT; EVANS, 2014; BROOK et al., 2016).

In this sense, STST was shown as an effective strategy to improve MDVC in the lower limbs of older people. By means of the metaanalysis it was possible to observe that, for each unit of MDVC increase in the control group, the experimental group increased $105 \%$. With only six weeks of traditional strength training, some studies (CORREA et al., 2012; SCALON et al., 2014; EMERSON et al., 2015; PINTO et al., 2014) found increases in MDVC, with effect sizes between 0.93 and 1.57. These increases in MDVC are important for the elderly, especially because muscle weakness is the main risk factor for falls, increasing the risk of falls by five times (BORDE; HORTOBÁGYI; GRANACHER, 2015; MUEHLBAUER; GOLLHOFER; GRANACHER, 2015). In addition, MDVC is also involved in functional capacity maintenance in older people, with muscle strength being a strong predictor of functional limitation and disability (BUCH et al., 2016; BORDE; HORTOBÁGYI; GRANACHER, 2015; SCHAAP; KOSTER; VISSER, 2013), associated with 1.86 times more chances of impairment in functional capacity (BRADY; STRAIGHT; EVANS, 2014). Thus, it is possible to think that a STST program is a quick strategy to prevent functional losses, disability and fall risk, through its positive effects on MDVC.

Similarly, STST also proves to be effective to improve MIVC in the lower limbs of older people. With four weeks of explosive strength training (2 sessions per week), Kobayashi et al. (2016) showed improvements in lower limbs MIVC of older people. In the same line, eight weeks of traditional strength training, two or three times a week, were also able to produce MIVC increases (GURJÃO et al., 2012; MEJÍAS-PEÑA et al., 2017; RODRIGUEZ-MIGUELEZ et al., 2014). On the other hand, the study of Smoralek et al. (2014) was the only one who did not find increases in MIVC, after 12 weeks of traditional strength training. The MIVC is important for posture maintenance and body stability, in some actions of daily life and also in sports practice (BELLAR; MARCUS; JUDGE, 2015; ROMERO-FRANCO; JIMÉNEZ-REYES; MONTAÑO-MUNUERA, 2017). Thus, a STST program could aid in the preservation of postural hygiene, body stability and some actions of everyday life in the elderly.

Lower limbs muscle power of older people also increased in response to STST. For each unit of muscle power increase in the control group, the experimental group showed a 79\% increase. Increases in muscle power were reported in 12-week studies (VALLS et al., 2014; SAYERS; GIBSON, 2014; RAMIREZ-CAMPILLO et al., 2017; RAMIREZ-CAMPILLO et al., 2014; ZECH et al., 2012). These results are important since muscle power is the best predictor of functional autonomy in older people, being strongly associated with gait velocity, balance and functionality in general. It is the most important strength manifestation for carrying out activities of daily living, such as climbing stairs, getting up from a chair or moving around the house (BRADY; STRAIGHT; EVANS, 2014).

However, aging seems to be associated with the loss or morphological alteration of cortical neurons, which in older people result in a $43 \%$ 
reduction in cortical neurons' volume (MCKINNON et al., 2017). It is also observed a reduction in the number of Schwann cells associated with myelinated nerve fibers in peripheral nervous system, resulting in a decrease in axonal conduction velocity and reduction of neurons efficiency in the transmission of motor commands to the muscles (MCKINNON et al., 2017). These structural changes in neurons, both in the central and peripheral nervous systems, can affect the ability to transmit and perform motor tasks, as well as muscle power. In addition, the aging process also promotes deterioration of coupling mechanism, excitationcontraction coupling and/or other responsible subcellular mechanisms in the muscular power generation (CARTEE et al., 2016). Thus, STST can be an effective strategy when it is would like to increase muscular power and the functional autonomy of the elderly, being able to slow down and/or reverse the degenerative effects of aging on that strength manifestation.

Functional capacity can be defined as the potential presented by the elderly to perform their daily activities independently (BARBOSA et al., 2014). During aging, it is possible to observe a decrease in functional capacity, mainly due to physical functions deterioration, such as a function decrease in the muscular, circulatory, respiratory and nervous systems (GLUCHOWSKI et al., 2015; WITARD et al., 2016), a situation that may hinder or impede the elderly perform in their daily activities.

In this study, data from two tests, TUG and CST, were used as indicators of functional capacity. STST promoted a reduction in the time taken to perform the TUG in people with 65 years old or older, indicating an improvement in the ability to move with changes of direction. By means of metaanalysis it was possible to observe that, for each unit of time decreased in the TUG by the control group, the experimental group decreased that time by $101 \%$. With just six weeks of traditional strength training, twice a week, Pinto et al. (2014) observed a decrease in TUG execution time. With the same training time and type, Fragala et al. (2014) reported similar results. Likewise, Granacher et al. (2013) demonstrated improvements in this test performance after nine weeks of functional strength training. Two other studies by the same research group (RAMIREZ-CAMPILLO et al., 2017; RAMIREZCAMPILLO et al., 2014) indicate that TUG performance also improves after 12 weeks of highspeed strength training.

In this line, STST was also effective in improving the performance of older people on the
CST test. For each unit of increase in this test in the control group, the experimental group presented an increase of $107 \%$. Different studies (CORREA et al., 2012; FRAGALA et al., 2014; PINTO et al., 2014) observed an increase in the number of actions performed in this test after six weeks of traditional strength training. Similarly, studies using 12 weeks of traditional strength training (LEE; PARK, 2013; VALLS et al., 2014; SMORALEK et al., 2014) or high-speed strength training (RAMIREZCAMPILLO et al., 2017; RAMIREZ-CAMPILLO et al., 2014) also showed similar results in people with 65 years old or older.

These improvements in performance of functional capacity tests may indicate that STST is capable of promoting an increase in physical capacity, in particular of motor functions, with reflexes on locomotive capacity improvement and on lower limbs functionality. This is especially important because STST, in addition to impacting functional capacity, can contribute to a decrease in risk of falls, since lower limbs muscle weakness and functional capacity loss are the main risk factors for falls in older people (BORDE; HORTOBÁGYI; GRANACHER, 2015; MUEHLBAUER; GOLLHOFER; GRANACHER, 2015).

Aging is associated with changes in body composition resulting in decreased MM, increases in trunk FM and fat infiltration in tissues and organs (JURA; KOZAK, 2016; KALISH, 2016; ZAMBONI et al., 2014; SCHAAP; KOSTER; VISSER, 2013). These changes in body composition cause a functional autonomy reduction, as well as the development of chronic diseases and premature mortality (KIM et al., 2016; JURA; KOZAK, 2016; BRADY; STRAIGHT; EVANS, 2014). Strength training and nutrition seem to be the main strategy to control changes in body composition caused by aging (BUCH et al., 2016). However, STST has not demonstrated statistically significant results (Z: 1.5, $\mathrm{p}=0.13$, SMD: $0.28,95 \% \mathrm{CI}:-0.08$; 0.60 ) for $\mathrm{MM}$ gain in people with 65 year old or older (CORREA et al., 2012; DELSHAD et al., 2013; KOBAYASHI et al., 2016; FRANK et al., 2016; PINTO et al., 2014). This result is in agreement with a metaanalysis by Peterson et al. (2011), which analyzed the strength training effects on MM of people older than 50 years of both sexes. The meantime to produce a gain of $1.1 \mathrm{~kg}$ of $\mathrm{MM}$ in people over 50 was 20.5 weeks of training (PETERSON et al., 2011).

In the same line, STST was also unable to promote a significant reduction of FM in people with 65 years or older $(Z: 0.62 ; p=0.54$; SMD: $0.18 ; 95 \% \mathrm{CI}:-0.75 ; 0.39)$. Of all the studies 
analyzed, the only one who observed a FM reduction after performing a STST was the one by Zhao et al. (2017), in 17 older male subjects who underwent 12 weeks of traditional strength training twice a week. Perhaps, as with MM, training time is not sufficient to produce significant adaptations in the adipocytes of older people. Thus, it seems that STST programs are not an effective strategy when it is intended to increase $\mathrm{MM}$ and reduce FM, and longer training programs should be used.

This systematic review presents some limitations, such as the methodological differences between the studies analyzed, both in the training program design and in the evaluation methods for variables of interest, which may have influenced the results. Finally, due to the eligibility criteria used to determine inclusion in this study, it is important to generalize our results with caution. For example, the participants in the studies analyzed were healthy older people, and extrapolation of STST effect on the different muscle strength manifestations in the lower limbs, functional capacity and body composition to other populations of older people, including those with mobility limitations or an associated disease, should be done with caution.

This meta-analysis provides a quantitative estimate of STST effects on different muscle strength manifestations in the lower limbs, functional capacity and body composition of people 65 years old or older. Available evidence indicates that STST has a moderate to large effect on MDVC, MIVC, muscle power and functional capacity as measured by the TUG and CST tests, when compared to the control group. However, this intervention seems to have no effect on MM and
FM. Given that aging causes functional autonomy deterioration, the implementation of STST interventions through public health initiatives can be a quick and efficient strategy to reduce the risk of functional impairment and physical disability among older people in the community.

\section{Future perspectives}

The systematic review and the results found will be able to serve as a useful tool in training prescription and in the design of conditioning programs aimed at quick gains of muscle strength and functional capacity.

The use of short-term interventions will be able to increase strength levels in older people and may contribute to improved functional autonomy and physical conditioning to support higher loads in long-term training programs.

In some surgical interventions on people of all ages, especially older people, it is recommended that the patient gain muscle strength before the intervention, with the aim of improving the intervention success chances and minimizing its side-effects. Thus, STST could also be an auxiliary strategy for the rapid gain of muscle strength, prior to a surgical intervention.

\section{ACKNOWLEDGMENT}

This work was supported by Coordenação de Aperfeiçoamento de Pessoal de Nivel Superior CAPES [BEX 11928/13-1]; Conselho Nacional de Desenvolvimento Científico e Tecnológico (CNPq) [207231/2014-1]; and Plan Nacional I+D+I [DEP2013-47659, Spain].

RESUMO: Examinar os efeitos do treinamento de força de curta duração (TFCD) em diferentes manifestações de força muscular nos membros inferiores, capacidade funcional e composição corporal de pessoas maiores de 65 anos. Foram pesquisadas bases de dados eletrônicas (PubMed, Web of Science e Cochrane) para identificar todas as publicações utilizando TFCD (até 12 semanas) em pessoas maiores de 65 anos, publicadas nos últimos cinco anos, antes de maio de 2018. Os resultados foram analisados como dados contínuos usando efeitos aleatórios para calcular a diferença padronizada da média (SMD) e o intervalo de confiança de 95\% (IC95\%). 28 estudos com 921 sujeitos preencheram os critérios de inclusão e foram analisados. Esses trabalhos foram agrupados em três categorias para análise: Força Muscular, Capacidade Funcional e Composição Corporal. Na categoria Força Muscular, a estimativa geral do efeito combinado foi de $0,95$ (95\% CI: 0,$63 ; 1,26)$, com um efeito significativo do TFCD $(Z=5,93 ; p<0,001)$, sobre as diferentes manifestações de força analisadas. Na categoria Capacidade Funcional, o TFCD diminuiu o tempo de execução do teste Timed Up-and-Go (SMD: $-1.01 ; 95 \%$ CI: -1.56; -0.47) e aumentou o número de repetições realizadas no teste de levantar e sentar na cadeira de 30 segundos (SMD: 1,07, IC 95\%: 0,79, 1,34). Na categoria de Composição Corporal, a estimativa geral do efeito combinado foi de 0,13 (IC 95\%: -0,16; 0,42), sem encontrar efeito significativo do TFCD $(Z=0,87 ; p=0,38)$. O TFCD apresenta efeito moderado a grande na melhora das diferentes manifestações de força muscular e capacidade funcional. No entanto, este tipo de intervenção não tem efeito sobre a composição corporal. 
PALAVRAS-CHAVE: Treinamento resistido. Força muscular. Força muscular. Composição corporal. Idoso.

\section{REFERENCES}

AMERICAN COLLEGE OF SPORTS MEDICINEICINE. American College of Sports Medicineicine position stand. Quantity and quality of exercise for developing and maintaining cardiorespiratory, musculoskeletal, and neuromotor fitness in apparently healthy adults: guidance for prescribing exercise. Medicine \& Science in Sports \& Exercise, v. 43, n. 7, p. 134-1359, 2011. https://doi.org/10.1249/MSS.0b013e318213fefb

AMERICAN COLLEGE OF SPORTS MEDICINEICINE. American College of Sports Medicineicine position stand. Exercise and physical activity for older adults. Medicine \& Science in Sports \& Exercise, v. 41, n. 7, p. 1510-1530, 2009. https://doi.org/10.1249/MSS.0b013e3181a0c95c

BARBOSA, B. R.; ALMEIDA, J.M.; BARBOSA, M.R.; ROSSI-BARBOSA, L.A. Evaluation of the functional capacity of the elderly and factors associated with disability. Ciência \& Saúde Coletiva, v. 19, n. 8, p. 33173325, 2014. https://doi.org/10.1590/1413-81232014198.06322013

BELLAR, D.; MARCUS, L.; JUDGE, L.W. Validation and Reliability of a Novel Test of Upper Body Isometric Strength. Journal of Human Kinetics, v. 47, p. 189-195, 2015. https://doi.org/10.1515/hukin-20150074

BORDE, R.; HORTOBÁGYI, T.; GRANACHER, U. Dose-response relationships of resistance training in healthy old adults: A systematic review and meta-analysis. Sports Medicine, v. 45, n. 12, p. 1693-1720, 2015. https://doi.org/10.1007/s40279-015-0385-9

BRADY, A. O.; STRAIGHT, C. R.; EVANS, E. M. Body composition, muscle capacity, and physical function in older adults: an integrated conceptual model. Journal of Aging and Physical Activity, v. 22, n. 3, p. 441452, 2014. https://doi.org/10.1123/JAPA.2013-0009

BROOK, M. S.; WILKINSON, D. J.; PHILLIPS, B. E.; PEREZ-SCHINDLER, J.; PHILP, A.; SMITH, K.; ATHESTON, P. J. Skeletal muscle homeostasis and plasticity in youth and ageing: impact of nutrition and exercise. Acta Physiologica, v. 216, n. 1, p. 15-41, 2016. https://doi.org/10.1111/apha.12532

BUCH, A.; CARMELI, E.; BOKER, L. K.; MARCUS, Y.; SHEFER, G.; KIS, O.; BERNER, Y.; STERN, N. Muscle function and fat content in relation to sarcopenia, obesity and frailty of old age--An overview.

Experimental Gerontology, v. 76, p. 25-32, 2016. https://doi.org/10.1016/j.exger.2016.01.008

CARTEE, G. D.; HEPPLE, R. T.; BAMMAN, M. M.; ZIERATH, J. R. Exercise Promotes Healthy Aging of Skeletal Muscle. Cell Metabolism, v. 23, n.6, p. 1034-1047, 2016. https://doi.org/10.1016/j.cmet.2016.05.007

CORREA, C. S.; LAROCHE, D. P.; CADORE, E. L.; REISCHAK-OLIVEIRA, A.; BOTTARO, M.; KRUEL, L. F.; TARTARUGA, M. P.; RADAELLI, R.; WILHELM, E. N.; LACERDA, F. C.; GAYA, A. R.; PINTO, R. S. 3 Different types of strength training in older women. International Journal of Sports Medicine, v. 33, n. 12, p. 962-969, 2012. https://doi.org/10.1055/s-0032-1312648

CURTIS, E.; LITWIC, A.; COOPER, C.; DENNISON, E. Determinants of Muscle and Bone Aging. Journal of Cellular Physiology, v. 230, n. 11, p. 2618-2625, 2015. https://doi.org/10.1002/jcp.25001 
DELSHAD, M.; GHANBARIAN, A.; MEHRABI, Y.; SARVGHADI, F.; EBRAHIM, K. Effect of Strength Training and Short-term Detraining on Muscle Mass in Women Aged Over 50 Years Old. International Journal of Preventive Medicine, v. 4, n. 12, p. 1386-1394, 2013.

EMERSON, N. S.; STOUT, J. R.; FUKUDA, D. H.; ROBINSON, E. H.; SCANLON, T. C.; BEYER, K. S.; FRAGALA, M. S.; HOFFMAN, J. R. Resistance training improves capacity to delay neuromuscular fatigue in older adults. Archives of Gerontology and Geriatrics, v. 61, n. 1, p. 27-32, 2015.

https://doi.org/10.1016/j.archger.2015.04.002

FARINATTI, P.; NETO, S. R.; DIAS, I.; CUNHA, F. A.; BOUSKELA, E.; KRAEMER-AGUIAR, L. G. Short-Term Resistance Training Attenuates Cardiac Autonomic Dysfunction in Obese Adolescents. Pediatric Exercise Science, v. 28, n. 3, p. 374-380, 2016. https://doi.org/10.1123/pes.2015-0191

FRAGALA, M. S.; FUKUDA, D. H.; STOUT, J. R.; TOWNSEND, J. R.; EMERSON, N. S.; BOONE, C. H.; BEYER, K. S.; OLIVEIRA, L. P.; HOFFMAN, J. R. Muscle quality index improves with resistance exercise training in older adults. Experimental Gerontology, v. 53, p. 1-6, 2014.

https://doi.org/10.1016/j.exger.2014.01.027

FRANK, P.; ANDERSSON, E.; PONTÉN, M.; EKBLOM, B.; EKBLOM, M.; SAHLIN, K. Strength training improves muscle aerobic capacity and glucose tolerance in elderly. Scandinavian Journal of Medicine \& Science in Sports, v. 26, n. 7, p. 764-773, 2016. https://doi.org/10.1111/sms.12537

GENNUSO, K. P.; ZALEWSKI, K.; CASHIN, S. E.; STRATH, S. J. Resistance training congruent with minimal guidelines improves function in older adults: a pilot study. Journal of Physical Activity and Health, v. 10, n. 6, p. 769-776, 2013. https://doi.org/10.1123/jpah.10.6.769

GERAGE, A. M.; FORJAZ, C. L.; NASCIMENTO, M. A.; JANUÁRIO, R. S.; POLITO, M. D.; CYRINO, E. S. Cardiovascular adaptations to resistance training in elderly postmenopausal women. International Journal of Sports Medicine, v. 34, n. 9, p. 806-813, 2013. https://doi.org/10.1055/s-0032-1331185

GLUCHOWSKI, A.; HARRIS, N.; DULSON, D.; CRONIN, J. Chronic Eccentric Exercise and the Older Adult. Sports Medicine, v. 45, n. 10, p. 1413-1430, 2015. https://doi.org/10.1007/s40279-015-0373-0

GRANACHER, U.; LACROIX, A.; MUEHLBAUER, T.; ROETTGER, K.; GOLLHOFER, A. Effects of core instability strength training on trunk muscle strength, spinal mobility, dynamic balance and functional mobility in older adults. Gerontology, v. 59, n. 2, p. 105-113, 2013. https://doi.org/10.1159/000343152

GURJÃO, A. L.; GOBBI, L. T.; CARNEIRO, N. H.; GONÇALVES, R.; FERREIRA DE MOURA, R.; CYRINO, E. S.; ALTIMARI, L. R.; GOBBI, S. Effect of strength training on rate of force development in older women. Research Quarterly for Exercise and Sport, v. 83, n. 2, p. 268-275, 2012.

https://doi.org/10.1080/02701367.2012.10599857

JURA, M.; KOZAK, L. P. Obesity and related consequences to ageing. Age (Dordr), v. 38, n. 1, p. 23, 2016. https://doi.org/10.1007/s11357-016-9884-3 
KALISH, V. B. Obesity in Older Adults. Primary Care, v. 43, n. 1, p. 137-144, 2016. https://doi.org/10.1016/j.pop.2015.10.002

KIM, H. J.; SO, B.; CHOI, M.; KANG, D.; SONG, W. Resistance exercise training increases the expression of irisin concomitant with improvement of muscle function in aging mice and humans. Experimental Gerontology, v. 70, p. 11-17, 2015. https://doi.org/10.1016/j.exger.2015.07.006

KIM, J. E.; O'CONNOR, L. E.; SANDS, L. P.; SLEBODNIK, M. B.; CAMPBELL, W. W. Effects of dietary protein intake on body composition changes after weight loss in older adults: a systematic review and metaanalysis. Nutrition Reviews, v. 74, n. 3, p. 210-224, 2016. https://doi.org/10.1093/nutrit/nuv065

KIMURA, K.; OBUCHI, S.; ARAI, T.; NAGASAWA, H.; SHIBA, Y.; WATANABE, S.; KOJIMA, M. The influence of short-term strength training on health-related quality of life and executive cognitive function. Journal of Physiological Anthropology, v. 29, n. 3, p. 95-101, 2010. https://doi.org/10.2114/jpa2.29.95

KOBAYASHI, Y.; UEYASU, Y.; YAMASHITA, Y.; AKAGI, R. Effects of 4 Weeks of Explosive-type Strength Training for the Plantar Flexors on the Rate of Torque Development and Postural Stability in Elderly Individuals. International Journal of Sports Medicine, v. 37, n. 6, p. 470-475, 2016.

https://doi.org/10.1055/s-0035-1569367

LEE, I. H.; PARK, S. Y. Balance improvement by strength training for the elderly. Journal of Physical Therapy Science, v. 25, n. 12, p. 1591-1593, 2013. https://doi.org/10.1589/jpts.25.1591

LOHNE-SEILER, H.; TORSTVEIT, M. K.; ANDERSSEN, S. A. Traditional versus functional strength training: effects on muscle strength and power in the elderly. Journal of Aging and Physical Activity, v. 21, n. 1, p. 51-70, 2013. https://doi.org/10.1123/japa.21.1.51

LORENTZON, M.; CUMMINGS, S. R. Osteoporosis: the evolution of a diagnosis. Journal of Internal Medicine, v. 277, n. 6, p. 650-661, 2015. https://doi.org/10.1111/joim.12369

LOWNDES, J.; CARPENTER, R.L.; ZOELLER, R.F.; SEIP, R.L.; MOYNA, N.M.; PRICE, T.B.; CLARKSON, P.M.; GORDON, P.M.; PESCATELLO, L.S.; VISICH, P.S.; DEVANEY, J.M.; GORDISHDRESSMAN, H.; HOFFMAN, E.P.; THOMPSON, P.D.; ANGELOPOULOS, T.J. Association of age with muscle size and strength before and after short-term resistance training in young adults. Journal of Strength \& Conditioning Research, v.23, n.7, p.1915-1920, 2009. https://doi.org/10.1519/JSC.0b013e3181b94b35

LUBANS, D.R.; MUNDEY, C.M.; LUBANS, N.J.; LONSDALE, C.C. Pilot randomized controlled trial: elastic-resistance-training and lifestyle-activity intervention for sedentary older adults. Journal of Aging and Physical Activity, v.21, n.1, p.20-32, 2013. https://doi.org/10.1123/japa.21.1.20

MAROTO-IZQUIERDO, S.; GARCÍA-LÓPEZ, D.; FERNANDEZ-GONZALO, R.; MOREIRA, O.C.; GONZÁLEZ-GALLEGO, J.; DE PAZ, J.A. Skeletal muscle functional and structural adaptations after eccentric overload flywheel resistance training: a systematic review and meta-analysis. Journal of Science and Medicine in Sport, v. 20, n.10, p.943-951, 2017. https://doi.org/10.1016/j.jsams.2017.03.004

MARTINS, W.R.; SAFONS, M.P.; BOTTARO, M.; BLASCZYK, J.C.; DINIZ, L.R.; FONSECA, R.M.; BONINI-ROCHA, A.C.; DE OLIVEIRA, R.J. Effects of short term elastic resistance training on muscle mass 
and strength in untrained older adults: a randomized clinical trial. BMC Geriatrics, v.15, p.99, 2015. https://doi.org/10.1186/s12877-015-0101-5

MATOS, D.G.; MAZINI FILHO, M.L.; MOREIRA, O.C.; DE OLIVEIRA, C.E.; DE OLIVEIRA VENTURINI, G.R.; DA SILVA-GRIGOLETTO, M.E.; AIDAR, F.J. Effects of eight weeks of functional training in the functional autonomy of elderly women: a pilot study. Journal of Sports Medicine and Physical Fitness, v.57, n.3, p.272-277, 2017. doi: 10.23736/S0022-4707.16.06514-2.

MAZINI FILHO, M.L.; AIDAR, F.J.; GAMA DE MATOS, D.; COSTA MOREIRA, O.; PATROCÍNIO DE OLIVEIRA, C.E.; DE OLIVEIRA VENTURINI, G.R.; MAGALHÃES CURTY, V.; MENEZES

TOUGUINHA, H.; CAPUTO FERREIRA, M.E. Circuit strength training improves muscle strength.; functional performance and anthropometric indicators in sedentary elderly women. Journal of Sports Medicine and Physical Fitness, v.58, n.7-8, p.1029-1103, 2018.

MCKINNON, N.B.; CONNELLY, D.M.; RICE, C.L.; HUNTER, S.W.; DOHESTY, T.J. Neuromuscular contributions to the age-related reduction in muscle power: Mechanisms and potential role of high velocity power training. Ageing Research Reviews, v.35, p.147-154, 2017. https://doi.org/10.1016/j.arr.2016.09.003

MEJÍAS-PEÑA, Y.; ESTÉBANEZ, B.; RODRIGUEZ-MIGUELEZ, P.; FERNANDEZ-GONZALO, R.; ALMAR, M.; DE PAZ, J.A.; GONZÁLEZ-GALLEGO, J.; CUEVAS, M.J. Impact of resistance training on the autophagy-inflammation-apoptosis crosstalk in elderly subjects. Aging (Albany NY), v.9, n.2. p.408-418, 2017. https://doi.org/10.18632/aging.101167

MORAN, J.; SANDERCOCK, G.R.; RAMÍREZ-CAMPILLO, R.; MEYLAN, C.; COLLISON, J.; PARRY, D.A. A meta-analysis of maturation-related variation in adolescent boy athletes' adaptations to short-term resistance training. Journal of Sports Sciences, v.35, n.11, p.1041-1051, 2017. https://doi.org/10.1080/02640414.2016.1209306

MUEHLBAUER, T.; GOLLHOFER, A.; GRANACHER, U. Associations Between Measures of Balance and Lower-Extremity Muscle Strength/Power in Healthy Individuals Across the Lifespan: A Systematic Review and Meta-Analysis. Sports Medicine, v.45, n.12, p.1671-1692, 2015. https://doi.org/10.1007/s40279-0150390-z

PETERSON, M.D.; SEN, A.; GORDON, P.M. Influence of resistance exercise on lean body mass in aging adults: a meta-analysis. Medicine \& Science in Sports \& Exercise, v.43, n.2, p.249-258, 2011. https://doi.org/10.1249/MSS.0b013e3181eb6265

PINTO, R.S.; CORREA, C.S.; RADAELLI, R.; CADORE, E.L.; BROWN, L.E.; BOTTARO, M. Short-term strength training improves muscle quality and functional capacity of elderly women. Age (Dordr), v.36, n.1, p.365-372, 2014. https://doi.org/10.1007/s11357-013-9567-2

RAMÍREZ-CAMPILLO, R.; CASTILLO, A.; DE LA FUENTE, C.I.; CAMPOS-JARA, C.; ANDRADE, D.C.; ÁlVAREZ, C.; MARTÍNEZ, C.; CASTRO-SEPÚlVEDA, M.; PEREIRA, A.; MARQUES, M.C.; IZQUIERDO, M. High-speed resistance training is more effective than low-speed resistance training to increase functional capacity and muscle performance in older women. Experimental Gerontology, v.58, p.5157, 2014. https://doi.org/10.1016/j.exger.2014.07.001 
RAMÍREZ-CAMPILLO, R.; MARTÍNEZ, C.; DE LA FUENTE, C.I.; CADORE, E.L.; MARQUES, M.C.; NAKAMURA, F.Y.; LOTURCO, I.; CANIUQUEO, A.; CAÑAS, R.; IZQUIERDO, M. High-Speed Resistance Training in Older Women: The Role of Supervision. Journal of Aging and Physical Activity, v.25, n.1, p.1-9, 2017. https://doi.org/10.1123/japa.2015-0122

RODRIGUEZ-MIGUELEZ, P.; FERNANDEZ-GONZALO, R.; ALMAR, M.; MEJÍAS, Y.; RIVAS, A.; DE PAZ, J.A.; CUEVAS, M.J.; GONZÁLEZ-GALLEGO, J. Role of Toll-like receptor 2 and 4 signaling pathways on the inflammatory response to resistance training in elderly subjects. Age (Dordr), v.36, n.6, p.9734, 2014. https://doi.org/10.1007/s11357-014-9734-0

ROMERO-FRANCO, N.; JIMÉNEZ-REYES, P.; MONTAÑO-MUNUERA, J.A. Validity and reliability of a low-cost digital dynamometer for measuring isometric strength of lower limb. Journal of Sports Sciences, v.35, n.22, p.2179-2184, 2017. https://doi.org/10.1080/02640414.2016.1260152

SAYERS, S.P.; GIBSON, K. High-speed power training in older adults: a shift of the external resistance at which peak power is produced. Journal of Strength \& Conditioning Research, v.28, n.3, p.616-621, 2014. https://doi.org/10.1519/JSC.0b013e3182a361b8

SCANLON, T.C.; FRAGALA, M.S.; STOUT, J.R.; EMERSON, N.S.; BEYER, K.S.; OLIVEIRA, L.P.; HOFFMAN, J.R. Muscle architecture and strength: adaptations to short-term resistance training in older adults. Muscle Nerve, v.49, n.4, p.584-592, 2014. https://doi.org/10.1002/mus.23969

SCHAAP, L.A.; KOSTER, A.; VISSER, M. Adiposity.; muscle mass.; and muscle strength in relation to functional decline in older persons. Epidemiology Reviews, v.35, p.51-65, 2013.

https://doi.org/10.1093/epirev/mxs006

SCOTT, D.; SEIBEL, M.; CUMMING, R.; NAGANATHAN, V.; BLYTH, F.; LE COUTEUR, D.G.; HANDELSMAN, D.J.; WAITE, L.M.; HIRANI, V. Sarcopenic Obesity and Its Temporal Associations With Changes in Bone Mineral Density.; Incident Falls.; and Fractures in Older Men: The Concord Health and Ageing in Men Project. Journal of Bone and Mineral Research, v.32, n.2, p.575-583, 2017. https://doi.org/10.1002/jbmr.3016

SILVA CORREA, C.; NESTOR WILHELM, E.; LUSA CADORE, E.; GEREMIA, J.; COSTA TEIXEIRA, B.; REISCHAK DE OLIVEIRA, A.; SILVEIRA PINTO, R. Strength training with stretch-shortening cycle exercises optimizes neuromuscular economy during functional tasks in elderly women. Science \& Sports, v.29, n.1, p.27-33, 2014. https://doi.org/10.1016/j.scispo.2013.04.005

SMOLAREK, A.C.; FERREIRA, L.H.; MASCARENHAS, L.P.; MCANULTY, S.R.; VARELA, K.D.; DANGUI, M.C.; DE BARROS, M.P.; UTTER, A.C.; SOUZA-JUNIOR, T.P. The effects of strength training on cognitive performance in elderly women. Clinical Interventions in Aging, v.11, p.749-754, 2016. https://doi.org/10.2147/CIA.S102126

VALLS, M.R.B.; DIMAURO, I.; BRUNELLI, A.; TRANCHITA, E.; CIMINELLI, E.; CASEROTTI, P.; DURANTI, G.; SABATINI, S.; PARISI, P.; PARISI, A.; CAPOROSSI, D. Explosive type of moderateresistance training induces functional.; cardiovascular.; and molecular adaptations in the elderly. Age (Dordr), v.36, n.2, p.759-772, 2014. https://doi.org/10.1007/s11357-013-9584-1 
WALKER, S.; HÄKKINEN, K. Similar increases in strength after short-term resistance training due to different neuromuscular adaptations in young and older men. Journal of Strength \& Conditioning Research, v.28, n.11, p.3041-3048, 2014. https://doi.org/10.1519/JSC.0000000000000381

WITARD, O.C.; MCGLORY, C.; HAMILTON, D.L.; PHILLIPS, S.M. Growing older with health and vitality: a nexus of physical activity.; exercise and nutrition. Biogerontology, v.17, n.3, p.529-546, 2016.

https://doi.org/10.1007/s10522-016-9637-9

ZAMBONI, M.; ROSSI, A.P.; FANTIN, F.; ZAMBONI, G.; CHIRUMBOLO, S.; ZOICO, E.; MAZZALI, G. Adipose tissue.; diet and aging. Mechanisms of Ageing and Development, v.136-137, p.129-137, 2014. https://doi.org/10.1016/j.mad.2013.11.008

ZECH, A.; DREY, M.; FREIBERGER, E.; HENTSCHKE, C.; BAUER, J.M.; SIEBER, C.C.; PFEIFER, K. Residual effects of muscle strength and muscle power training and detraining on physical function in community-dwelling prefrail older adults: a randomized controlled trial. BMC Geriatrics, v.12, p.68, 2012. https://doi.org/10.1186/1471-2318-12-68

ZHANG, J.; RANE, G.; DAI, X.; SHANMUGAM, M.K.; ARFUSO, F.; SAMY, R.P.; LAI, M.K.; KAPPEI, D.;, KUMAR, A.P.; SETHI, G. Ageing and the telomere connection: An intimate relationship with inflammation. Ageing Research Reviews, v.25, p.55-69, 2016. https://doi.org/10.1016/j.arr.2015.11.006

ZHANG, J. Teaching the basics of autophagy and mitophagy to redox biologists-Mechanisms and experimental approaches. Redox Biology, v.4, p.242-259, 2015. https://doi.org/10.1016/j.redox.2015.01.003

ZHAO, J.; SU, Z.; QU, C.; DONG, Y. Effects of 12 Weeks Resistance Training on Serum Irisin in Older Male Adults. Frontiers in Physiology, v.8, p.171, 2017. https://doi.org/10.3389/fphys.2017.00171 